\title{
SHORT-CHAIN CHLORINATED PARAFFINS IN BIOTA - LEVELS AND EFFECTS
}

\author{
O.I. KALANTZI, * \\ R.A. ALCOCK ${ }^{2}$
}

\author{
${ }^{1}$ Department of Environment, University of the Aegean \\ University Hill, Mytilene, 81100, Greece \\ ${ }^{2}$ Lancaster Environment Centre, Lancaster University \\ Lancaster, LA1 4YQ, United Kingdom
}

Received: $20 / 12 / 11$

Accepted: 31/01/12

*to whom all correspondence should be addressed: e-mail: kalantzi@aegean.gr

\begin{abstract}
Short-chain chlorinated paraffins (SCCPs) are highly complex technical mixtures of polychlorinated $n$-alkanes with carbon-chain lengths from $\mathrm{C}_{10}-\mathrm{C}_{13}$ and chlorine content between 49 and $70 \%$. They are produced by chlorination of $n$-alkanes and do not occur naturally. Because of their physical properties (viscosity, flame resistance) they are used in many different applications, such as lubricant additives, PVC plasticizers and flame retardants in paints, adhesives and sealants. Among the chlorinated paraffin mixtures, SCCPs have the highest potential for release into the environment, because of their higher vapour pressure and water solubility (about 10-100 times higher than for PCBs).
\end{abstract}

SCCPs can reach the environment through production, storage or use, as well as through leeching, runoff and volatilization from contaminated areas. Despite the fact that they are one of the most challenging groups of compounds to quantify and analyze, SCCPs have been detected in biota and humans, as well as a variety of environmental matrices such as sediments and air. SCCPs have also been detected in remote places such as the Arctic (Reth et al., 2006) and dated sediment cores, suggesting long-range atmospheric transport and persistence in the environment. SCCPs have been found to be toxic to aquatic and soil organisms, fish and there is some evidence of carcinogenicity. This paper reviews the current state of knowledge and highlights the need for further research in order to improve future monitoring efforts.

KEYWORDS: short-chain chlorinated paraffins, analysis, environmental levels, toxicity.

\section{INTRODUCTION}

Chlorinated paraffins, also known as polychlorinated $n$-alkanes (PCAs), are a class of industrial chemicals comprising of chlorinated straight chain hydrocarbons. They are produced with free radical chlorination and have a wide range of applications, but are mainly used as extreme pressure lubricant additives, plasticizers, flame-retardants and paint additives (WHO, 1996). Since their introduction in the chemical market in the 1930s, their world production has increased to more than 300,000 t/year. PCAs are designated according to their carbon chain length: short chain chlorinated paraffins (SCCPs, or SPCAs) - $\mathrm{C}_{10-13}$; medium chain chlorinated paraffins (MCCPs, or mPCAs) $\mathrm{C}_{14-17}$; long chain chlorinated paraffins (LCCPs) - $\mathrm{C}_{18-30}$. In Europe total SSCP production in 1995 was estimated to be $\leq 15000$ tonnes (EC, 2000).

SCCPs are very complex chemicals - commercial formulations contain many thousands of individual molecular structures - which are difficult and challenging to analyze. Sample preparation usually involves extraction and cleanup (by either Soxhlet, Accelerated Solvent Extraction, Liquid Liquid Extraction, Solid Phase Extraction or Solid Phase Micro Extraction) and purification (by either concentrated sulphuric acid treatment, sulphuric acid silica gel chromatography or Gel Permeation Chromatography) (Eljarrat and Barcelo, 2006). GC-ECNI-MS is the most commonly used technique for SSCP analysis in environmental matrices (Lepom et al., 2009). Only two interlaboratory 
comparison studies have been conducted for SCCPs (Tomy et al., 1999; Pellizzato et al., 2009). The results of both studies showed great variability, in the older study because of the use of different external standard solutions, and in the most recent one because of differences in detection and calibration methods, confirming the challenging nature of SSCP analysis.

Following their widespread and diverse use, SCCPs can be found in a range of environmental samples, both biotic and abiotic (Tomy et al., 1998b; Muir et al., 2000). However, information on environmental levels is still scarce compared to other persistent organic chemicals (POPs) such as dioxins, PCBs and organochlorine pesticides. The EU has completed a formal environmental and human health risk assessment on SCCPs (UK Environment Agency, 1999). As a result, risk reduction measures have been implemented on SCCPs in Europe from 2004 (EC, 2002). SCCPs have been included in the list of priority hazardous substances of the European Water Framework Directive (EU Directive 200/60/EC). On July 26, 2006, the European Community and its Member States being Parties to the Stockholm Convention nominated SCCPs to be listed in Annexes A, B, or $\mathrm{C}$ of the Convention (UNEP/POPS/POPRC.2/INF/6). This paper reviews published data on the levels of SCCPs in the environment and their effects in organisms.

\section{ENVIRONMENTAL LEVELS}

Considering their low vapour pressure, low water solubility and lipophilic nature, SCCPs are likely to distribute mainly to the soil/sediment phase with little volatilization occurring. They are also likely to be transported as suspended particles in the water, and dust particles in the air (WHO, 1996). Release into the environment may occur during production, storage, usage and disposal of paraffincontaining products, as well as disposal and burning of waste, and land filling of products such as PVC, textiles, painted materials, paint cans and cutting oils (Tomy et al., 1998a). Most releases of SCCPs in wastewater and surface water are expected to be associated with metal working operations, however there is potential for widespread release in small amounts associated with uses in products (e.g. paints, textiles, rubber).

SCCPs have been detected in different environmental matrices. In the atmosphere, SCCPs were detected in samples from the Arctic in concentrations ranging from non-detectable to $8.5 \mathrm{pg} \mathrm{m}^{-3}$ in gas-phase samples. In the United Kingdom, Peters et al. (2000) reported a mean SCCP concentration of $99 \mathrm{pg} \mathrm{m}^{-3}$ in air collected from a semi rural site in Lancaster. In a later study, Barber et al. (2005) reported concentrations in the U.K. atmosphere ranging from $<185$ to $3430 \mathrm{pg} \mathrm{m}^{-3}$ (mean of $1130 \mathrm{pg} \mathrm{m}^{-3}$ ) and were higher than 1997 concentrations measured at the same site. This study also calculated an average concentration of $600 \mathrm{pg} \mathrm{m}^{-3}$ of SCCPs in the UK atmosphere.

In sewage sludge concentrations of SCCPs ranged from 6.9 to $200 \mu \mathrm{g} \mathrm{g}^{-1}$ dry weight (Stevens et al., 2002), with the highest concentrations being in sludge from industrial catchments. In marine sediments from Barcelona concentrations of SCCPs were much lower than those in the UK, in the range of 0.21 to $1.17 \mathrm{\mu g} \mathrm{g}^{-1}$ dry weight (Castells et al., 2008). In sediments from the North and Baltic Seas SCCPs ranged from 21-172 $\mathrm{ng} \mathrm{g}^{-1}$ dry weight (Hüttig and Oehme, 2005). A dated sediment core study from Lake Thun in Switzerland revealed a considerable deposition of SCCPs over a period of 30 years, from 1961 to 2004, with SSCP concentrations ranging from 5 to $51 \mathrm{ng} \mathrm{g}^{-1}$ (lozza et al., 2008). A study from Lake Ontario and Lake Michigan has shown their ubiquitous nature and widespread distribution and has revealed biomagnification factors for several SSCP isomers ranging from a 3-fold from rainbow smelt to lake trout, to a 23-fold from Diporeia to sculpin (Muir et al., 2003). This clearly suggests an increase through the trophic levels in aquatic food webs.

SCCPs have also been detected in marine wildlife, such as beluga (Delphinapterus leucas), ringed seal (Phoca hispida) and walrus (Odobenus rosmarus) blubber in the Canadian Arctic, in concentrations ranging from 0.095 to $0.626 \mathrm{mg} \mathrm{kg}^{-1}$ wet weight (Tomy et al., 1998b; 2000). It was observed in this study that the concentration profiles for the Arctic marine mammals show a predominance of the shorter carbon chain length congeners (the $C_{10}$ and $C_{11}$ groups). SCCPs have also been measured in the liver and muscle of seabirds from the European Arctic in concentrations ranging from 0.005 to $0.088 \mathrm{mg} \mathrm{kg}^{-1}$ wet weight (Reth et al., 2006).

For the terrestrial environment, the data is very limited. CEFAS (1999) reported the concentrations of 
SCCPs in earthworms from the UK ranging from $<0.1$ to $0.7 \mathrm{mg} \mathrm{kg}^{-1}$ dry weight. Campbell and McConnell (1980) determined levels of $C_{10-20}$ CPs in birds (100-1200 $\mathrm{g} \mathrm{kg}^{-1}$ wet weight) and seabird eggs (non-detect to $2000 \mathrm{\mu g} \mathrm{kg}^{-1}$ ) from the UK.

Concentrations in human tissues are very limited. A study from the United Kingdom has found SCCPs to be present in human breast milk at concentrations ranging from 49 and $820 \mathrm{ng} \mathrm{g}^{-1}$ fat (median $180 \mathrm{ng} \mathrm{g}^{-1}$ fat) (Thomas et al., 2006). Tomy (1997) measured SCCPs in human breast milk from Inuit women in Canada at a concentration of 11-17 $\mathrm{g} \mathrm{kg}^{-1}$ lipid (mean $13 \mu \mathrm{g} \mathrm{kg}^{-1}$ lipid). The only market basket study which was conducted for SCCPs estimated the 95th percentile of the total daily intake for 1-year-old Japanese female to be $6.8 \times 10^{2} \mathrm{ng} \mathrm{kg}^{-1}$ day and concluded that food intake is the main exposure pathway of SCCPs for Japanese people, but it does not pose a risk (lono et al., 2005).

It is thought that the main route of exposure to SCCPs is likely to be dermal, however inhalation and food may be important routes of uptake, because of their high Kow. SCCPs were the second most abundant group of compounds measured in indoor air of homes in France, with a mean concentration of $45 \mathrm{\mu g} \mathrm{g}^{-1}$ dust (Bonvallot et al., 2010). In the only survey of foodstuffs from the litareture, the highest concentration of chlorinated paraffins (average level of $\mathrm{C}_{10-20}: 300 \mu \mathrm{g} \mathrm{kg}^{-1}$ ) was present in dairy products (Campbell and McConnell, 1980). If we assume a daily consumption of dairy products of $1 \mathrm{~kg}$ per person, the daily intake of SCCPs and MCCPs would be $300 \mu \mathrm{g}(4.3 \mu \mathrm{g}$ $\mathrm{kg}^{-1}$ body weight, assuming an average body weight of $70 \mathrm{~kg}$ ).

\section{EFFECTS AND TOXICITY}

Early dietary exposure studies of juvenile rainbow trout (Oncorhynchus mykiss) with SCCPs showed rapid accumulation and high assimilation efficiencies from food (Fisk et al., 1998). Half-lives of SCCPs in rainbow trout ranged from 7 to 53 days and increased with increasing carbon chain length, chlorine content and Kow. SCCPs have been shown to decrease free and total plasma T4 concentrations, and double plasma TSH levels (Wyatt et al., 1993). Compared to MCCPs, SCCPs are more potent as peroxisome proliferators and may lead to thyroid follicular cell carcinogenesis, as observed in long-term studies with rats and mice (Wyatt et al., 1993). The International Agency for Research on Cancer (IARC) has concluded that there is sufficient evidence for the carcinogenicity of a commercial chlorinated paraffin product of average carbon chain length $\mathrm{C}_{12}$ and average degree of chlorination of $60 \%$ in experimental animals and "possibly carcinogenic to humans" (Group 2B) (IARC, 1990).

Experiments with freshwater and marine algae exposed to SCCPS $\left(\mathrm{C}_{10-12}, 58 \% \mathrm{Cl}\right)$ revealed a higher sensitivity of marine algae compared to freshwater algae, with an $\mathrm{EC}_{50}$ of $43 \mathrm{mg} \mathrm{L}^{-1}$, compared to $1,310 \mathrm{mg} \mathrm{L}^{-1}$ (Thompson and Madeley, 1983a; 1983b).

The effects of SCCPs on the survival and reproduction of five soil organisms (Fosomia candida, Eisenia fetida, Enchytraeus albidus, Enchytraeus crypticus, and Caenorhabditis elegans) were investigated by Bezchlebová et al. (2007). Folsomia candida (collembola) was most sensitive organism, with an $\mathrm{LC}_{50}$ for adult survival of $5733 \mathrm{mg} \mathrm{kg}^{-1}$ dry weight and $\mathrm{EC}_{50}$ and $\mathrm{EC}_{10}$ values for reproduction of 1230 and $660 \mathrm{mg} \mathrm{kg}^{-1}$ dry weight, respectively.

In a long-term study with laying hens, SCCPs were found in the highest concentrations in abdominal fat, in the yolk and the liver, in relation to the amounts ingested (Ueberschär et al., 2007). Half-lives ranged from 20-30 days for most tissues, and the input-output balance revealed the highest extraction amount (30\%) through manure and urine. In birds, both acute and chronic toxicity of SCCPs appears to be low. In a reproductive study with mallard ducks (Anas platyrynchos) fed with a diet of a $\mathrm{C}_{10-13}$ SCCP, a slight decrease in eggshell thickness and 14-day embryo viability were observed only at the highest dose (Serrone et al., 1987).

SCCPs do not seem to cause mutagenic effects in bacterial assays in vitro, or in rats (NTP, 1986; IRDC, 1983). In mammalian cells, the SSCP $\mathrm{C}_{12} ; 60 \% \mathrm{Cl}$ has been found to be mutagenic in mouse lymphoma cells (Myhr et al., 1990). Another in vitro study has shown that SCCPs may act as tumour promoters (Kato and Kenne, 1996). Limited data is available on neurotoxicity. A study with male 
mice observed a decreased motor capacity, after administration of male mice with a dose of $300 \mathrm{mg}$ $\mathrm{kg}^{-1}$ bw of SCCP $\left(\mathrm{C}_{10-13}, 49 \% \mathrm{Cl}\right)$ (Eriksson and Kihlström (1985).

\section{CONCLUDING REMARKS}

It is clear that sensitive analytical methods need to be established, in order to improve future monitoring efforts. Further research is needed in order to understand the mechanisms of toxicity of SCCPs. The neurotoxicity data is limited and the immunotoxicity data is non-existent. Despite some sporadic efforts to determine the influence of chain length and degree of chlorination, more information is needed on the dynamics, kinetics and metabolism of SCCPs. Toxicity studies in rodents and other animals indicate that chronic exposure to relatively low concentrations of SCCPS adversely affects their survival and development. Finally, more human biomonitoring data is needed, in order to understand the routes of uptake of these chemicals in the human body and the levels present in tissues.

It is evident that SCCPs may lead to adverse environmental and human health effects. Given their persistence, bioaccumulative nature and potential to undergo long-range transport, it is clear that action is required for the regulation of these chemicals.

\section{REFERENCES}

Barber J.L., Sweetman A.J., Thomas G.O., Braekevelt E., Stern G.A. and Jones K.C., (2005) Spatial and Temporal Variability in Air Concentrations of Short-Chain $\left(C_{10-C 13}\right)$ and Medium-Chain $\left(C_{14}-C_{17}\right)$ Chlorinated n-Alkanes Measured in the U.K. Atmosphere, Environmental Science \& Technology, 39(12), 4407-4415.

Bezchlebová J., Cernohlávková J., Kobeticová K., Lána J., Sochová I. and Hofman J., (2007) Effects of short-chain chlorinated paraffins on soil organisms, Ecotoxicol. Environ. Saf. 67, 206-211.

Bonvallot N., Mandin C., Mercier F., Le Bot B. and Glorennec P., (2010) Health ranking of ingested semivolatile organic compounds in house dust: an application to France, Indoor Air, 20: 458-472.

Campbell I. and McConnell G., (1980) Chlorinated paraffins and the environment. 1. Environmental occurrence, Environ Sci Technol, 14, 1209-1214.

Castells P., Parera J., Santos F.J. and Galceran M.T. (2008) Occurrence of polychlorinated napthalenes, polychlorinated biphenyls and short-chain chlorinated paraffins in marine sediments from Barcelona (Spain), Chemosphere, 70, 1552-1562.

EC (2000) European Union Risk Assessment Report - ALKANES, $\mathrm{C}_{10}{ }_{13}$, CHLORO CAS-No.: 8553584-8 EINECS-No: 287-476-5, EUR 19010 EN; Luxembourg.; 2000.

EC (2000) European Community, Directive 2000/60/EC of the European parliament and the council of 23 October 2000 establishing a framework for Community action in the field of water policy. Off. J. Euro. Communities, L 327, 1-72.

EC (2002) EC Directive 2002/45/EC of the European Parliament and of the Council amending for the 20th time Council Directive 76/769/EEC relating to restrictions on the marketing and use of certain dangerous substances and preparations (short-chain chlorinated paraffins, 25 June 2002); European Commission, Brussels.

Eljarrat E. and Barcelo D., (2006) Quantitative analysis of polychlorinated $n$-alkanes in environmental samples, Trends in Analytical Chemistry, 25 (4), 421-434.

Eriksson P. and Kihlström J., (1985) Disturbance of motor performance and thermoregulation in mice given two commercial chlorinated paraffins, Bull Environ Contam Toxicol 34:205-209.

Fisk A.A., Cymbalisty C.D., Tomy G.T. and Muir D.C.G., (1998) Dietary accumulation and depuration of C10, C11 and C14-polychlorinated alkanes by juvenile rainbow trout (Oncorhynchus mykiss ), Aquat. Toxicol., 43, 209-221.

Hüttig J. and Oehme M., (2005) Presence of chlorinated paraffins in sediments from the North and Baltic Seas, Arch. Environ. Contam. Toxicol., 49, 449-456.

IARC (International Agency for Research on Cancer) (1990) Summaries and evaluations. Chlorinated paraffins (Group 2B), vol 48, p 55.

lino F., Takasuga T., Senthilkumar K., Nakamura N. and Nakanishi J., (2005) Risk Assessment of ShortChain Chlorinated Paraffins in Japan Based on the First Market Basket Study and Species Sensitivity Distributions, Environmental Science \& Technology, 39(3), 859-866. 
lozza S., Müller C.E., Bogdal C., Schmid P. and Oehme M., (2008) Historical profiles of chlorinated paraffins and polychlorinated biphenyls in a dated sediment core from Lake Thun (Switzerland), Environmental Science and Technology, 42, 1045-1050.

IRDC (International Research and Development Corporation (1983) Dominant lethal study in rats. Chlorinated paraffin: $58 \%$ chlorination of short chain $n$-paraffins. International Research and Development Corporation, Mattawan, MI, pp 54 (Report No 438-011).

Kato Y. and Kenne K. (1996) Inhibition of cell-cell communication by commercial chlorinated paraffins in rat liver epithelial IAR 20 cells, Pharmacol. Toxicol., 79, 23-28.

Lepom P., Brown B., Hanke G., Loos R., Quevauviller P. and Wollgast J., (2009) Needs for reliable analytical methods for monitoring chemical pollutants in surface water under the European Water Framework Directive, J. Chromatogr. A, 1216(3), 302-315.

Muir D., Teixeira C., Braekevelt E., Tomy G. and Whittle M., (2003) Medium chain chlorinated paraffins in Great Lakes food webs, Organohalogen Compd. 64, 166-169.

Myhr B., McGregor D., Bowers L., Riach C., Brown A.G., Edwards I., McBride D., Martin R. and Caspary W.J., (1990) L5178Y mouse lymphoma cell mutation assay results with 41 compounds, Environ. Mol. Mutagen., 16(Suppl 18), 138-167.

Muir D.C.G., Stern G.A. and Tomy G.T. (2000) The Handbook of Environmental Chemistry, SpringerVerlag, Berlin.

NTP (The National Toxicology Program) (1986) NTP technical report on the toxicology and carcinogenesis studies of chlorinated paraffins $\left(\mathrm{C}_{12}, 60 \%\right.$ chlorine) (CAS No. 63449-39-8) in $\mathrm{F} 344 / \mathrm{N}$ Rats and B6C3F1 Mice (Gavage Studies). NTP TR 308, NIH Publication No. 86-2564, Research Triangle Park, NC, USA.

Pellizzato F., Ricci M., Held A. and Emons H., (2007) Analysis of short-chain chlorinated paraffins: a discussion paper, Journal of environmental monitoring, 9, 924-30.

Pellizzato, F., Ricci, M., Held, A., Emons, H., Bohmer, W., Geiss, S., lozza, S., Mais, S., Petersen M. and Lepom P., (2009) Laboratory intercomparison study on the analysis of short-chain chlorinated paraffins in an extract of industrial soil, Trends in Analytical Chemistry, 28 (8), 1029-1035.

Peters A.J., Tomy G.T., Jones K.C., Coleman P. and Stern G.A., (2000) Occurrence of C10-C13 polychlorinated $\mathrm{n}$-alkanes in the atmosphere of the United Kingdom, Atmos. Environ., 34, 3085-3090.

Pribylova P., Klanova J. and Holoubek I., (2006) Screening of short- and medium-chain chlorinated paraffins in selected riverine sediments and sludge from the Czech Republic, Environmental Pollution, 144(1), 248-254.

Reth M., Ciric A., Christensen G.N., Heimstad E.S. and Oehme M., (2006) Short- and medium-chain chlorinated paraffins in biota from the European Arctic - differences in homologue group patterns, Science of The Total Environment, 367(1), 252-260.

Serrone D.M., Birtley R.D.N., Weigand W. and Millischer R., (1987) Toxicology of chlorinated paraffins, Food Chem. Toxicol. 25, 553-562.

Thomas G.O., Farrar D., Braekevelt E., Stern G., Kalantzi O.I., Martin F.L. and Jones K.C., (2006) Short and medium chain length chlorinated paraffins in UK human milk fat, Environment International, 32(1), 34-40.

Thompson R.S. and Madeley J.R., (1983a) Toxicity of a chlorinated paraffin to the marine algae Skeletonema costatum. Imperial Chemical Industries PLC, Devon, England (Brixham Report No $\mathrm{BL} / \mathrm{B} / 2328)$

Thompson R.S. and Madeley J.R., (1983b) Toxicity of a chlorinated paraffin to the green algae Selenastrum capricornutum. Imperial Chemical Industries PLC, Devon, England (Brixham Report No $\mathrm{BL} / \mathrm{B} / 2321)$

Tomy G., Stern G., Koczanski K. and Halldorson T., (1998b) Polychloro-n-alkanes in beluga whales from the Arctic and the St. Lawrence River estuary, Organohalogen Compd., 35, 399-401.

Tomy G.T., (1997). The mass spectrometric characterization of polychlorinated n-alkanes and the methodology for their analysis in the environment. Thesis, University of Manitoba, Winnipeg, Manitoba.

Tomy G.T., Fisk, A.T., Westmore J.B. and Muir D.C.G., (1998a) Environmental chemistry and toxicology of polychlorinated $n$-alkanes, Rev. Environ. Contam. Toxicol., 158, 53-128.

Tomy G.T., Westmore J.B., Stern G.A., Muir D.C.G. and Fisk A.T., (1999) Interlaboratory Study on Quantitative Methods of Analysis of C10-C13 Polychloro-n-alkanes, Analytical Chemistry, 71(2), 446451. 
Ueberschär K-H., Dänicke S. and Matthes S., (2007) Dose-response feeding study of short chain chlorinated paraffins (SCCPs) in laying hens: Effects on laying performance and tissue distribution, accumulation and elimination kinetics, Mol. Nutr. Food Res., 51, 248-254.

UK Environment Agency (1999) Risk assessment of alkanes, C $_{10-13}$, chloro; Final Draft.

WHO, (1996). International programme on chemical safety, Environmental Health Criteria 181: Chlorinated Paraffins, WHO, Geneva.

Wyatt I., Coutts C.T. and Elcombe C.R., (1993) The effect of chlorinated paraffins on hepatic enzymes and thyroid hormones, Toxicology, 77, 81-90. 